\title{
Sensory and Physical Characteristic of Gluten-Free Nastar Cookies
}

\author{
Andian Ari Anggraeni, Titin Hera Widi Handayani \\ Faculty of Engineering \\ Universitas Negeri Yogyakarta \\ Yogyakarta, Indonesia \\ andian_ari@uny.ac.id, titin_hwh@uny.ac.id
}

\begin{abstract}
This research was performed to assess the sensory and physical characteristics of gluten-free nastar cookies. Nastar cookies are popular cookies in Indonesia, usually made from wheat flour. Recently it has been a challenge to substitute wheat flour with locally-grown-crop flour. Composite flour based on modified cassava flour (MCF) has been used to replace wheat flour (WF). Isolated soy protein (ISP) and hydrocolloids such as xanthan gum (XG) or guar gum (GG) were used to improve the sensory and physical quality of gluten-free nastar cookies. The combination of MCF with rice flour (RF), ISP and XG or GG in different concentration to produce nastar cookies was reported in this research. Five formulations of cookies were prepared from: (a) control (100\% WF), (b) MCF 75\%, RF 20\%, ISP 5\%, XG $2 \%$ flour based, (c) MCF 75\%, RF 20\%, ISP 5\%, XG $2.5 \%$ flour based, (d) MCF 75\%, RF 20\%, ISP 5\%, GG 2\% flour based, and (e) MCF 75\%, RF 20\%, ISP 5\%, GG 2.5\% flour based. Cookies were assessed for physical analysis (diameter, thickness, spread ratio, breaking strength and color analysis) and subjected to consumer acceptance by sensory analysis (color, flavor, texture, taste, and overall acceptability). Nastar cookies prepared from $\mathbf{7 5 \%}$ modified cassava flour, $20 \%$ rice flour, $5 \%$ isolated soy protein and addition of $2 \%$ guar gum were more acceptable than cookies prepared from other gluten-free formulations and the sensory characteristics (color, flavor, texture, taste and overall acceptability) were not significantly different $(\mathbf{P}>0.05)$ from control-wheat-flour nastar cookies.
\end{abstract}

Keywords- cookies; nastar; mocaf; modified cassava flour; gluten-free

\section{INTRODUCTION}

Indonesia was reported to be number four biggest population country in the world. The total population in 2012 was 245.9 million [1]. It leads to the great demand of staple food, such as rice and wheat. The demand for imported rice and wheat raise significantly. This problem threatens Indonesia's food security. To encourage food security, the government of Indonesia supports the intensification of locally grown crops production and food diversification.

Bakery product (bread, cake, cookie) which is commonly made from wheat flour is encouraged to substitute with locallygrown-crop flour. The use of gluten-free composite flour in bakery product is expected to meet customer acceptance in sensory and physical characteristic.

Cassava (Manihot esculenta) is a staple food in Indonesia, but it is less popular than rice, wheat, and corn. Cassava is tolerant to drought and pest attack, grows well under critical conditions of water and soil nutrition. The harvesting time ranges from 6 to 18 months after planting, so that farmers are allowed to keep the roots in the ground until needed. Cassava production in Indonesia has increased from 17,2 million in 1993 to 23,4 million in 2014 [2]. Cassava can be converted to produce many food products, such as food for direct consumption, cassava chips, cassava flour, cassava starch flour and modified cassava flour (mocaf). Mocaf is more acceptable than regular cassava flour because the sensory characteristic of mocaf is alike wheat flour (white, soft and cassava odorless). Mocaf is also lower price than rice flour and around the same price with wheat flour.

Intensification of cassava production needs product conversion. The formulation of cookies made from mocaf has not yet fully developed. Our preliminary research showed that the total substitution of mocaf to the wheat flour resulted in cookies having a less acceptable sensory characteristic, especially for texture. To support the intensification of cassava production, it is necessary to improve the quality of bakery product made from mocaf.

Soy-flour can be used as an improver in cookies to increase dough handling characteristics and protein quality [3]. The cassava cookies with the incorporation of soy-flour were accepted by the consumers in the sensory characteristic of color, taste, and crispiness but not for the texture [4]. It was reported that the use of non-starch hydrocolloids such as xanthan gum to gluten-free flours copies the gluten viscoelastic properties [5]. Reference [6] also reported other hydrocolloids, such as pectin and guar gum.

Nastar cookies are popular in Indonesia, commonly made from wheat flour. The dough is made from wheat flour, margarine, butter, egg yolk, powder sugar, and dry milk. Pineapple jam is placed in the center of the dough, shaped into round ball and baked until golden brown. Nastar cookies are melted in the mouth.

The objective of this research was to design composite flour comprising of mocaf, rice flour, isolated soy protein, xanthan gum or guar gum. The composite flour is baked to produce nastar cookies. The sensory and physical analysis of the composite flour nastar cookies were determined. 


\section{MATERIALS AND METHODS}

\section{A. Materials}

Materials used for cookies preparation were wheat (Triticum aestivum) flour (WF), mocaf (MCF), rice (Oryza sativa) flour (RF), isolated soy protein (ISP), guar gum (GG), xanthan gum (XG), margarine, butter, powder sugar, egg yolk, dry milk, pineapple, sugar, cinnamon and clove. Mocaf was obtained from Putri 21, Gunung Kidul, Yogyakarta. Isolated soy protein was purchased from Shandong Crown Soya Protein Co. Ltd. Guar gum was purchased from Hindustan Gum \& Chemicals Limited. Xanthan gum was bought from CV. Nura Jaya. And other materials were purchased from commercial brands in the local market of Yogyakarta.

\section{B. Cookies Preparation}

Nastar cookies were made from several blends of flour and hydrocolloids (guar gum or xanthan gum). The ingredients used in the preparation of cookies are shown in TABLE I.

TABLE I. COOKIES INGREDIENTS

\begin{tabular}{|l|r|r|r|r|r|}
\hline \multicolumn{1}{|c|}{ Ingredients (g) } & Control & XG-2 & XG-2.5 & GG-2 & GG-2.5 \\
\hline Wheat flour & 100.0 & - & - & - & - \\
\hline Mocaf & - & 75.0 & 75.0 & 75.0 & 75.0 \\
\hline Rice flour & - & 20.0 & 20.0 & 20.0 & 20.0 \\
\hline Isolated soy protein & - & 5.0 & 5.0 & 5.0 & 5.0 \\
\hline Xanthan gum & - & 2.0 & 2.5 & - & - \\
\hline Guar gum & - & - & - & 2.0 & 2.5 \\
\hline Margarine & 48.0 & 48.0 & 48.0 & 48.0 & 48.0 \\
\hline Butter & 25.0 & 25.0 & 25.0 & 25.0 & 25.0 \\
\hline Powder sugar & 18.0 & 18.0 & 18.0 & 18.0 & 18.0 \\
\hline Egg yolk & 17.0 & 17.0 & 17.0 & 17.0 & 17.0 \\
\hline Dry milk & 3.6 & 3.6 & 3.6 & 3.6 & 3.6 \\
\hline
\end{tabular}

Pineapple jam was prepared first. One piece of pineapple was grated, and then mixed with 100 gram sugar, $2 \mathrm{~cm}$ cinnamon and 2 pcs clove. The mixture was boiled until the texture become thick and then put aside. Margarine, butter, egg yolk, powder sugar and dry milk were mixed until light, fluffy and creamy. Wheat flour, mocaf, rice flour, isolated soy protein, and xanthan gum or guar gum were added to the cream dough and blended well. Around 8 grams batter was weighed and flattened. Pineapple jam was placed in the center of the batter and then shaped into round ball. The dough was set at $155^{\circ} \mathrm{C}$ at the top and $160{ }^{\circ} \mathrm{C}$ at the bottom and baked for 40 minutes. The well-baked cookies were placed to cooling down to room temperature and kept in low-density polyethylene (LDPE) pouches inside air tight container until further use for sensory and physical analysis.

\section{Sensory Analysis}

The sensory characteristics of cookies were analyzed evaluated using hedonic scale test. 60 semi-trained panelists were asked to evaluate sensory characteristics such as color, flavor, texture, taste, and overall acceptability. Cookies samples were evaluated after 24 hours. Cookies samples were randomly ordered and placed in coded LDPE pouches. Tap water was prepared to clean the mouth between the evaluation. The panelists were asked to evaluate the sensory characteristics using 9-Point Hedonic Score System. The panelist marks the cookies from 9 to 1, ranging from 'like extremely' to 'disliked extremely' to determine the most acceptable composition of cookies.

\section{Physical Analysis}

Physical characteristics such as diameter (D), thickness (T), spread factor (SF) were decided according to AACC procedure [7]. The diameter of cookies was determined by horizontally putting six cookies edge to edge and rotating $90^{\circ}$ for duplicate reading and taking average diameter. Thickness was determined by stacking six cookies on top of each other and taking average thickness. All the measurement were done in duplicates of six cookies. Spread ratio was determined by dividing the average value of diameter by average value of thickness. Spread factor was the ratio of the spread ratio of the control sample to that of the composite samples.

\section{E. Color Analysis}

Cookies were subjected to color analysis using a chromameter Konica Minolta CR 400. The results were expressed in $\mathrm{L}^{*} \mathrm{a} * \mathrm{~b} *$ color model. $\mathrm{L}^{*}$ values indicate lightness from black to white ( 0 to 100$)$, a* values measure greenness from -60 to 0 and redness from 0 to 60 . And $b^{*}$ values indicate blueness form -60 to 0 and yellowness from 0 to 60 . All the readings were performed in duplicate and taking an average.

\section{F. Textural Determination}

The maximum breaking strength $(\mathrm{N})$ of cookies was determined by compression test using a Texture Analyzer with a $0.02 \mathrm{~N}$ pre-load force and test speed of $10 \mathrm{~mm} / \mathrm{min}$. Cookies were compressed in the texturometer until breaking. The measurements were performed in duplicates to find out the average value.

\section{G. Statistic}

Experiments were performed in two replicates, the results were subjected to analysis of variance (ANOVA). The significance of difference between the average values was evaluated using Duncan comparison test $(\mathrm{P} \leq 5 \%)$.

\section{RESULTS AND DISCUSSION}

\section{A. Cookies Composition}

Nastar cookies are very popular cookies in Indonesia, made from $100 \%$ wheat flour. Our preliminary study showed that nastar cookies made from $100 \%$ mocaf resulted in unacceptable sensory characteristic (color, flavor, texture, taste and overall acceptability) [8]. To reduce dependancy to imported staple food, composite flour of $75 \%$ modified cassava flour, $20 \%$ rice flour and $5 \%$ isolated soy protein was used to replace wheat flour in nastar cookies. To improve the sensory characteristics of nastar cookies, hydrocolloid such as xanthan gum and guar gum was added to the ingredients. Control cookies were made from $100 \%$ wheat flour. All samples cookies (XG-2, XG-2.5, GG-2 dan GG-2.5) were made from composite flour. The four samples differed in the concentration of hydrocolloid. XG-2 and XG-2.5 used 2\% and 2.5\% xanthan 
gum, respectively. And GG-2 and GG-2.5 used 2\% and $2.5 \%$ guar gum, respectively.

\section{B. Sensory Analysis}

TABLE II showed the sensory analysis of nastar cookies. The wheat flour control had the highest overall acceptability of 8.4. Sample GG-2 had overall acceptability of 8.0, showing no significant different with control $(\mathrm{P}>0.05)$. The use of guar gum in composite flour based nastar cookies improved the overall acceptability. The results also showed that the incorporation of guar gum in nastar cookies was more acceptable than xanthan gum.

TABLE II. SENSORY ANALYSIS OF COOKIES

\begin{tabular}{|l|r|r|r|r|r|}
\hline Sample & Color & Flavor & Texture & Taste & $\begin{array}{c}\text { Overall } \\
\text { Acceptability }\end{array}$ \\
\hline Control & $8.4^{\mathrm{a}}$ & $8.0^{\mathrm{a}}$ & $7.8^{\mathrm{a}}$ & $8.3^{\mathrm{a}}$ & $8.4^{\mathrm{a}}$ \\
\hline $\mathrm{XG}-2$ & $6.2^{\mathrm{b}}$ & $6.8^{\mathrm{c}}$ & $6.4^{\mathrm{b}}$ & $6.1^{\mathrm{c}}$ & $6.2^{\mathrm{c}}$ \\
\hline XG-2.5 & $6.6^{\mathrm{b}}$ & $7.3^{\mathrm{bc}}$ & $5.9^{\mathrm{b}}$ & $6.4^{\mathrm{c}}$ & $6.4^{\mathrm{c}}$ \\
\hline GG-2 & $7.8^{\mathrm{a}}$ & $7.6^{\mathrm{ab}}$ & $7.7^{\mathrm{a}}$ & $7.8^{\mathrm{a}}$ & $8.0^{\mathrm{ab}}$ \\
\hline GG-2.5 & $6.4^{\mathrm{b}}$ & $7.4^{\mathrm{b}}$ & $7.6^{\mathrm{a}}$ & $7.2^{\mathrm{b}}$ & $7.4^{\mathrm{b}}$ \\
\hline
\end{tabular}

Columns with the same superscripts are not significantly different at $\mathrm{P} \leq 0.05$

Control contain 100\% WF. Sample XG-2 contain MCF 75\%, RF 20\%, ISP 5\%, XG $2 \%$ flour based. Sample XG-2.5 contain MCF 75\%, RF 20\%, ISP 5\%, XG 2.5\% flour based. Sample GG2 contain MCF 75\%, RF 20\%, ISP 5\%, GG 2\% flour based. Sample GG-2.5 contain MCF 75\%, RF 20\%, ISP 5\%, GG $2.5 \%$ flour based.

All sensory characteristic (color, flavor, texture, taste and overall acceptability) of sample GG-2 showed no significant different with control $(\mathrm{P}>0.05)$. The results indicated that blend of guar gum $2 \%$ in composite flour improve the sensory characteristic of nastar cookies. The addition of guar gum to mocaf-based composite flour was encouraging as it does not change the sensory characteristic of nastar cookies.

\section{Physical Analysis}

The physical characteristics of nastar cookies prepared from different blends of flours were shown in TABLE III. The diameter of all cookies composition varied from 2.72 to 2.94 $\mathrm{cm}$. The thickness of all types of cookies ranged from 2.27 to $2.35 \mathrm{~cm}$. The spread ratio ranged from 1.17 to 1.29 . Cookies made from composite flour showed smaller spread ratio than that of control, although there was no significant difference $(\mathrm{P}>0.05)$. The spread ratio was important to assess the quality of the biscuits [9]. Biscuits with high spread ratio values were better [10]. Composite flour based nastar cookies with $2 \%$ guar gum had the highest spread ratio among all composite flour cookies. The results showed that diameter, thickness and spread ratio of all cookies had no significant difference $(\mathrm{P}>0.05)$ between all types of cookies. The physical analysis indicated that the addition of hydrocolloid $2 \%$ to $2.5 \%$ in composite flour contribute to maintaining the physical properties of nastar cookies. No changes in physical parameters (diameter, thickness, spread ration) were advisable because otherwise, the final shape of the cookies would have been affected and thus, not demanding to consumers.

Gluten-free cookies formulation without any improver (isolated soy protein and hydrocolloids) were reported to increase the cookies hardness significantly [11, 12]. Our preliminary research also showed that the substitution of wheat flour $100 \%$ to mocaf without the addition of isolated soy protein and hydrocolloid resulted in increasing hardness of cookies texture [8].

TABLE III. PHYSICAL CHARACTERISTIC OF COOKIES

\begin{tabular}{|l|r|r|r|r|r|}
\hline Sample & $\begin{array}{c}\text { Diameter } \\
\text { cm }\end{array}$ & $\begin{array}{c}\text { Thickness } \\
\text { cm }\end{array}$ & $\begin{array}{c}\text { Spread } \\
\text { Ratio }\end{array}$ & $\begin{array}{c}\text { Spread } \\
\text { Factor }\end{array}$ & $\begin{array}{c}\text { Breaking } \\
\text { Strength } \\
\text { N }\end{array}$ \\
\hline Control & $2.94^{\mathrm{a}}$ & $2.29^{\mathrm{a}}$ & $1.29^{\mathrm{a}}$ & $1.00^{\mathrm{a}}$ & $3.25^{\mathrm{a}}$ \\
\hline $\mathrm{XG}-2$ & $2.75^{\mathrm{a}}$ & $2.34^{\mathrm{a}}$ & $1.17^{\mathrm{a}}$ & $1.10^{\mathrm{a}}$ & $7.71^{\mathrm{a}}$ \\
\hline $\mathrm{XG}-2.5$ & $2.85^{\mathrm{a}}$ & $2.35^{\mathrm{a}}$ & $1.21^{\mathrm{a}}$ & $1.06^{\mathrm{a}}$ & $8.50^{\mathrm{a}}$ \\
\hline GG-2 & $2.79^{\mathrm{a}}$ & $2.27^{\mathrm{a}}$ & $1.23^{\mathrm{a}}$ & $1.05^{\mathrm{a}}$ & $4.20^{\mathrm{a}}$ \\
\hline GG-2.5 & $2.72^{\mathrm{a}}$ & $2.32^{\mathrm{a}}$ & $1.17^{\mathrm{a}}$ & $1.10^{\mathrm{a}}$ & $3.66^{\mathrm{a}}$ \\
\hline
\end{tabular}

Control contain 100\% WF. Sample XG-2 contain MCF 75\%, RF 20\%, ISP 5\%, XG $2 \%$ flour based. Sample XG-2.5 contain MCF 75\%, RF 20\%, ISP 5\%, XG 2.5\% flour based. Sample GG2 contain MCF 75\%, RF 20\%, ISP 5\%, GG 2\% flour based. Sample GG- 2.5 contain MCF 75\%, RF 20\%, ISP 5\%, GG 2.5\% flour based.

This study incorporated isolated soy protein and hydrocolloids in all of the composite flour cookies ingredient. TABLE III showed that the incorporation of hydrocolloid in the gluten-free formulation slightly increased the cookies hardness, but it was proved to be no significant different with control cookies $(\mathrm{P}>0.05)$. The present study indicated that the addition of hydrocolloid had successful effects to maintain cookies hardness.

\section{Color Determination}

The initial acceptability of cookies by consumers was first decided by the color of the top and bottom surface of cookies [13]. The color of the cookie surfaces was resulted from nonenzymatic browning (Maillard) reactions between amino acids and reducing sugars as well as from starch dextrinization and sugar caramelization [14]. TABLE IV presented the effect of gluten-free cookies formulation on color measurement.

TABLE IV. COLOR CHARACTERISTICS OF COOKIES

\begin{tabular}{|l|r|r|r|}
\hline \multicolumn{1}{|c|}{ Sample } & \multicolumn{1}{c|}{$\mathbf{L}^{*}$} & \multicolumn{1}{c|}{$\mathbf{a}^{*}$} & $\mathbf{b}^{*}$ \\
\hline Control & $57.81^{\mathrm{a}}$ & $10.12^{\mathrm{a}}$ & $45.04^{\mathrm{a}}$ \\
\hline XG-2 & $53.06^{\mathrm{a}}$ & $15.29^{\mathrm{a}}$ & $37.07^{\mathrm{a}}$ \\
\hline XG-2.5 & $54.37^{\mathrm{a}}$ & $13.73^{\mathrm{a}}$ & $38.93^{\mathrm{a}}$ \\
\hline GG-2 & $56.49^{\mathrm{a}}$ & $15.25^{\mathrm{a}}$ & $42.91^{\mathrm{a}}$ \\
\hline GG-2.5 & $52.44^{\mathrm{a}}$ & $14.98^{\mathrm{a}}$ & $41.52^{\mathrm{a}}$ \\
\hline
\end{tabular}

Control contain $100 \%$ WF. Sample XG-2 contain MCF 75\%, RF 20\%, ISP 5\%, XG $2 \%$ flour based. Sample XG-2.5 contain MCF 75\%, RF 20\%, ISP 5\%, XG 2.5\% flour based. Sample GG2 contain MCF 75\%, RF 20\%, ISP 5\%, GG 2\% flour based. Sample GG-2.5 contain MCF 75\%, RF $20 \%$, ISP $5 \%$, GG $2.5 \%$ flour based.

The lightness $\left(\mathrm{L}^{*}\right)$ of the cookies varied from 52.44 to 57.81 , but it showed no significant difference between samples $(\mathrm{P}>0.05)$. The use of gluten-free flour slightly reduced the cookies lightness. Reference [15] also reported that increased substitution of wheat flour with cassava and water chestnut flour reduced the lightness. The redness $\left(\mathrm{a}^{*}\right)$ and yellowness (b*) also showed no significant difference between samples $(\mathrm{P}>0.05)$. The results of this research indicated that the addition of hydrocolloids does not affect the color of gluten-free cookies surface. 


\section{CONCLUSION}

Food technologist in Indonesia had been challenged to improve the formulation of gluten-free cookies, in order to reduce the dependency to imported wheat flour. The incorporation of $2 \%$ guar gum in the gluten-free nastar cookies formula $(75 \%$ modified cassava flour, $20 \%$ rice flour and $5 \%$ isolated soy protein) resulted in no significant different $(\mathrm{P}>0.05)$ with control wheat flour cookies on sensory and physical characteristics. The composite flour can be used to replace wheat flour in the production of nastar cookies.

\section{ACKNOWLEDGMENT}

This research was kindly funded by Penelitian Produk Terapan research grant from Ministry of Research, Technology and Higher Education, Republic of Indonesia.

\section{REFERENCES}

[1] Statistic Indonesia, Statistical Yearbook of Indonesia, BPS Catalog 1101001, ISSN 0126-2912, Jakarta: Statistic Indonesia, 2012.

[2] Statistic Indonesia, Viewed July 31, 2017, https://www.bps.go.id/ linkTableDinamis/view/id/880, 2015.

[3] J.I. Okoye, A.C. Nkwocha, and A.E. Ogbonnaya, "Production, proximate composition and consumer acceptability of biscuits from wheat/soybean flour blends," Continental Journal of Food Science and Technology, 2008, 2: 6-13.

[4] A.O. Obadina, O.B. Oyewole, and G. Olaniyi, "Effect of baking improvers on the quality of whole cassava biscuits," J. Food Sci. Technol., 2014, 51(10):2803-2808.

[5] A. Lazaridou, D. Duta, M. Papageorgiou, N. Belc, and C.G. Biliaderis, "Effects of hydrocolloids on dough rheology and bread quality parameters in gluten-free formulation," Journal of Food Engineering, 2007, 79(3): 1033-1047.
[6] T. Funami, Y. Kataoka, T. Omoto, Y. Goto, I. Asai, and K. Nishinari, "Effect of non-ionic polysaccharides on the gelatinization and retrogradation behavior of wheat starch," Food Hydrocolloids, 2005, 19:1-13.

[7] AACC, Approved Method of the American Association of Cereal Chemist, 10th ed., American Association of Cereal Chemist Press., St. Paul, MN., 2000.

[8] A.A. Anggraeni, T.H.W. Handayani, and S. Palupi, "Sensory Characteristic of Gluten-Free Popular Indonesian Cookies", Proceeding of International Conference on Technology and Vocational Teachers, 2017

[9] D. Bose, and M. Shams-Ud-Din, "The effect of chickpea (Cicer arietinim) husk on the properties of cracker biscuits," J. Bangladesh Agril. Univ., 2010, 8(1):147-152.

[10] H.A. Eissa, A.S. Hussein, and B.E. Mostafa, "Rheological properties and quality evaluation of Egyptian balady bread and biscuits supplemented with flours of ungerminated and germinated legume seeds or mushroom," Pol. J. Food Nutr. Sci., 2007, 57:487-496.

[11] S. Sarabhai, D. Indrani, M. Vijaykrishnaraj, Milind, V.A. Kumar, and P. Prabhasankar, "Effect of protein concentrates, emulsifiers on textural and sensory characteristics of gluten free cookies and its immunochemical validation," J. Food Sci. Technol., 2015, 52(6):37633772 .

[12] N.A.A. Aziah, M.A.Y. Noor, and L.H. Ho, "Physicochemical and organoleptic properties of cookies incorporated with legume flour,' International Food Research Journal, 2012, 19(4):1539-1543.

[13] F. Zucco, Y. Borsuk, and S.D. Arntfield, "Physical and nutritional evaluation of wheat cookies supplemented with pulse flours of different particle sizes,” LWT-Food Sci. Technol., 2011, 44:2070-2076.

[14] S. Chevallier, P. Colona, A. Buleon, and G.D. Valle, "Physicochemical behaviors of sugar, lipids, and gluten in short dough and biscuit," J. Agr. Food Chem., 2000, 48(4):1322-1326.

[15] A. Bala, K. Gul, and C.S. Riar, "Functional and sensory properties of cookies prepared from wheat flour supplemented with cassava and water chestnut flours," Cogent Food \& Agricultur., 2015, 1:1019815. 